\title{
Duplication of the left vertebral artery in a patient with dissection of the right internal carotid artery and Ehlers-Danlos syndrome: case report and review of the literature
}

\author{
Michał Polguj • Kazimierz Jędrzejewski • \\ Mirosław Topol · Julia Wieczorek-Pastusiak • \\ Agata Majos
}

Received: 14 April 2012/ Accepted: 16 August 2012/Published online: 7 September 2012

(C) The Author(s) 2012. This article is published with open access at Springerlink.com

\begin{abstract}
Duplication of the left vertebral artery was observed in a 43-year-old Caucasian male with dissection of the right internal carotid artery during multidetector 64-row computer tomography and Doppler ultrasonography B-flow mode. Both duplicated segments arose from the left subclavian artery and united at levels C5-C6 to form a single vessel. The presented case describes precisely the origin and diameter of both vertebral arteries. Additionally, after all procedures associated with diagnosis and treatment of the patient, Ehlers-Danlos syndrome type IV was diagnosed. The lumen of the duplicated vertebral artery was smaller than normal; it can be concluded that this variant has clinical implications and should be taken into consideration when vertebral arteries need catheterization.
\end{abstract}

Keywords Computer tomography angiography ·

Doppler ultrasonography · Duplication .

Ehlers-Danlos syndrome · Vertebral artery variation

\section{Introduction}

Variations of the origin and course of the vertebral arteries are uncommon, but extremely important to recognize in the

\section{Polguj ( $\square)$}

Department of Angiology, Medical University of Łódź,

Narutowicza 60, 90-136 Lodz, Poland

e-mail: michal.polguj@umed.lodz.pl

K. Jędrzejewski $\cdot$ M. Topol

Department of Normal and Clinical Anatomy,

Medical University of Łódź, Narutowicza 60,

90-136 Lodz, Poland

J. Wieczorek-Pastusiak · A. Majos

Radiology Department, Medical University of Łódź,

Kopcińskiego 22, 90-153 Lodz, Poland diagnosis, catheter-based evaluation and treatment of patients suffering cerebrovascular disease. One of the rarest anomalies is the duplication of the extracranial segments of vertebral arteries, which is usually an incidental finding in an autopsy series, angiographic studies or, more recently, MR and CT angiography and color Doppler studies (Harnier et al. 2008; Ionete and Omojola 2006; Kendi and Brace 2009; Mahmutyazicioglu et al. 1998).

The term "duplication of the vertebral artery" is applied to a vessel that has two origins with a variable level of fusion in the neck (Goddard et al. 2001; Ionete and Omojola 2006). Nevertheless, the precise definition of this anomaly is occasionally confused with "fenestration". However, "fenestration of the vertebral artery" refers to an artery with a single origin, with two parallel segments anywhere along its course and fusion (Goddard et al. 2001; Ionete and Omojola 2006). Both "duplication" and "fenestration" are variants of developmental abnormalities resulting from a failure of fetal vessels to involute (Lie 1972; Padget 1948; Sim et al. 2001). The main difference between duplications and fenestrations is that, in duplication, a vertebral artery has two origins, a variable course and fusion level in the neck. In contrast, fenestration refers to a vessel with a single origin, where the main trunk divides into two parallel segments anywhere along its course (Goddard et al. 2001; Harnier et al. 2008).

The frequency of fenestration of the vertebral artery is identified in $0.23-1.95 \%$ of angiographies or autopsy studies (Goddard et al. 2001; Sim et al. 2001). Duplication is much rarer, reported by Bergman et al. (1988) in $0.72 \%$ of studied cadavers.

This anomaly is often associated with significant cerebrovascular abnormalities such as symptomatic kinking, aneurysm, arterio-venous fistulae and arterio-venous malformations (Dare et al. 1997; Gaskill et al. 1996; Kendi and Brace 2009; Koenigsberg et al. 2003; Lie 1972; Thomas 


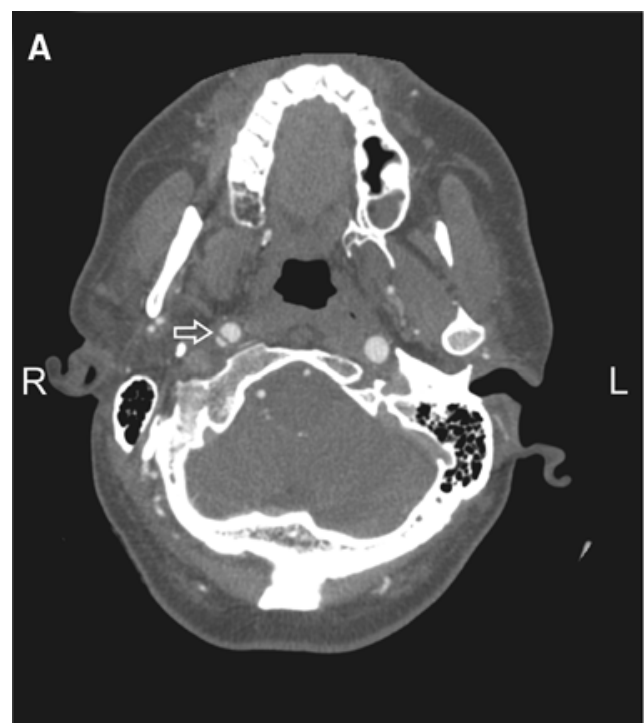

Fig. 1a, b Computer tomography (CT) of the neck and head. a Segmental dissections of the right internal carotid artery. b Infraction involving deep structures of the right hemisphere including

et al. 2008). It has been speculated that duplicated vertebral arteries may be more predisposed to dissection (Dare et al. 1997; Gaskill et al. 1996). Therefore, every description of a duplication of the vertebral artery associated with another anomaly or genetic disease is important, as each contributes to a database allowing a meta-analysis to be performed in the future.

\section{Case report}

A 43-year-old Caucasian man was admitted to the emergency department of our hospital for headache associated with weakness of the left limbs. He had no medical history, he denied even slight trauma of the neck, and his only cardiovascular risk factor was tobacco smoking for 10 years. Neurological examination revealed verbal aphasia and left hemiparesis.

During CT angiography (TK-64-row MDCT scanner, LightSpeed VCT, GE, Waukesha, WI) of the neck and head, segmental dissections of the right internal carotid artery (ICA) at the level of the cranial basis were discovered (Fig. 1a). The lumen of the ICA was decreased to $4 \times 2.5 \mathrm{~mm}$ ( $60 \%$ of normal flow). Cerebral CT showed a recent infarction involving the medial part of the right temporal lobe and deep structures of the right hemisphere including the thalamus, the genu and the posterior limb of the internal capsule (Fig. 1b).

CT angiography of the neck and head also showed a duplication of the left vertebral artery (LVA) with two origins, both from the left subclavian artery (Figs. 2, 3). The duplicated segments were fused at level of the C5-6

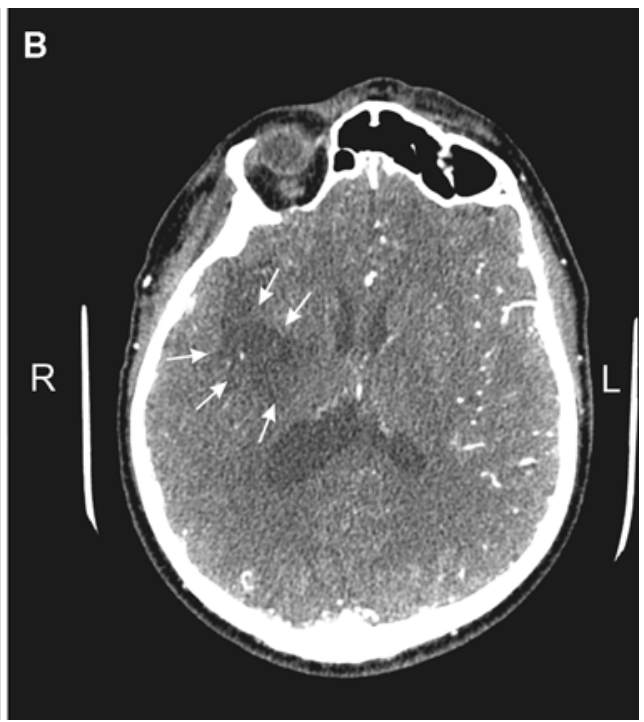

thalamus, genu and posterior limb of internal capsule, which on this single scan represent a part of the ischemic area

vertebrae into a single vertebral artery, which then entered the transverse foramen of C5 (Fig. 3). All measurements were taken on an Advantage Workstation (GE).

The first LVA originated from the left subclavian artery at a distance of $7 \mathrm{~mm}$ from the aortic arch. It measured 2.9 and $2.8 \mathrm{~mm}$ in diameter at the points of origin and just before fusion, respectively (Fig. 4). The course of the artery was $101 \mathrm{~mm}$. The second LVA arose from the left subclavian artery $37 \mathrm{~mm}$ distal to the first $(44 \mathrm{~mm}$ from the aortic arch). It measured 2.4 and $2.2 \mathrm{~mm}$ in diameter at the points of origin and just before fusion, respectively (Fig. 4), and its course was $89 \mathrm{~mm}$. Both vertebral arteries possessed a regular lumen. The diameter of the LVA after fusion was $3.3 \mathrm{~mm}$ (at level C5-6) (Fig. 4).

The right VA arose as the first branch from the left subclavian artery, $43 \mathrm{~mm}$ from the aortic arch. Its course was normal. The diameters of the right VA were $4 \mathrm{~mm}$ at the points of origin and $3.8 \mathrm{~mm}$ at the $\mathrm{C} 5-\mathrm{C} 6$ vertebrae (Fig. 4). Both thyrocervical trunks were seen to originate separately from the subclavian arteries.

Additionally, complementary but independent to CT angiography Doppler Sonography B-flow mode (Vivid 7 Pro, GE) of the vertebral arteries also revealed a duplicated LVA (Fig. 5).

After all procedures were completed, Ehlers-Danlos syndrome type IV was diagnosed.

\section{Discussion}

In most examples of a duplicated vertebral artery, the two roots originate from the aorta and the subclavian artery 


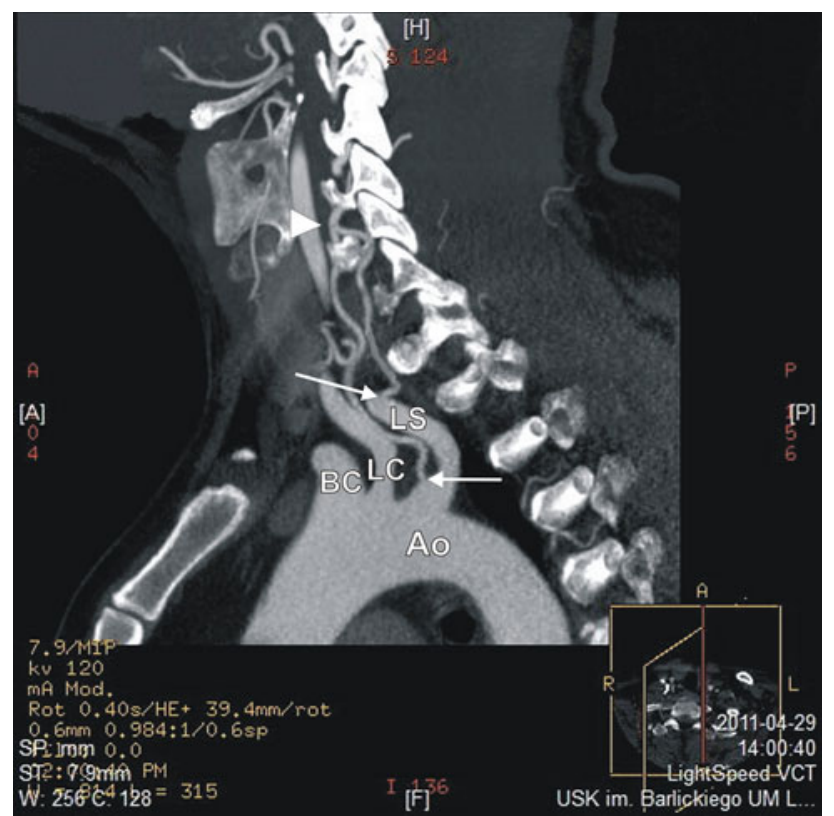

Fig. 2 Helical CT angiography, MPR reconstruction in sagittal plane of the neck and superior part of the thorax: arrows origins of the duplicated left vertebral arteries, arrowhead level of fusion of duplicated left vertebral arteries, $A o$ aortic arch, $B C$ brachiocephalic trunk, $L C$ left common carotid artery, $L S$ left subclavian artery

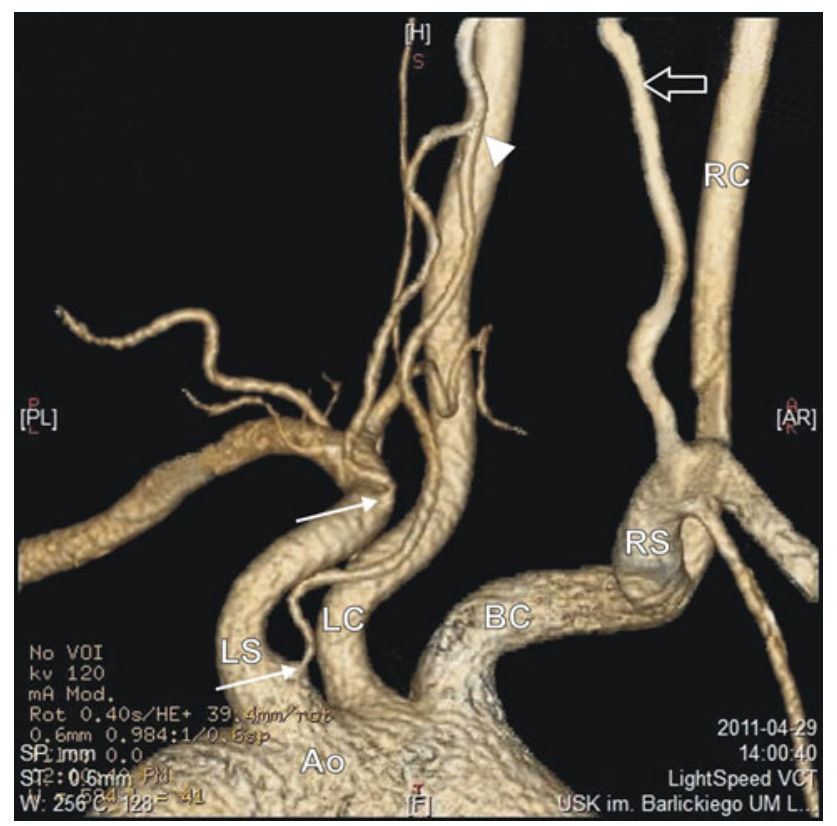

Fig. 3 Three-dimensional CT reconstruction of the arteries. White arrows origins of the duplicated left vertebral arteries, black arrow right vertebral artery, arrowhead level of fusion of duplicated left vertebral arteries, $A o$ aortic arch, $B C$ brachiocephalic trunk, $L C$ left common carotid artery, $L S$ left subclavian artery, $R C$ right common carotid artery, $R S$ right subclavian artery

(Kendi and Brace 2009; Koenigsberg et al. 2003; Mahmutyazicioglu et al. 1998; Suzuki et al. 1978). However, a second, more common situation occurs when,

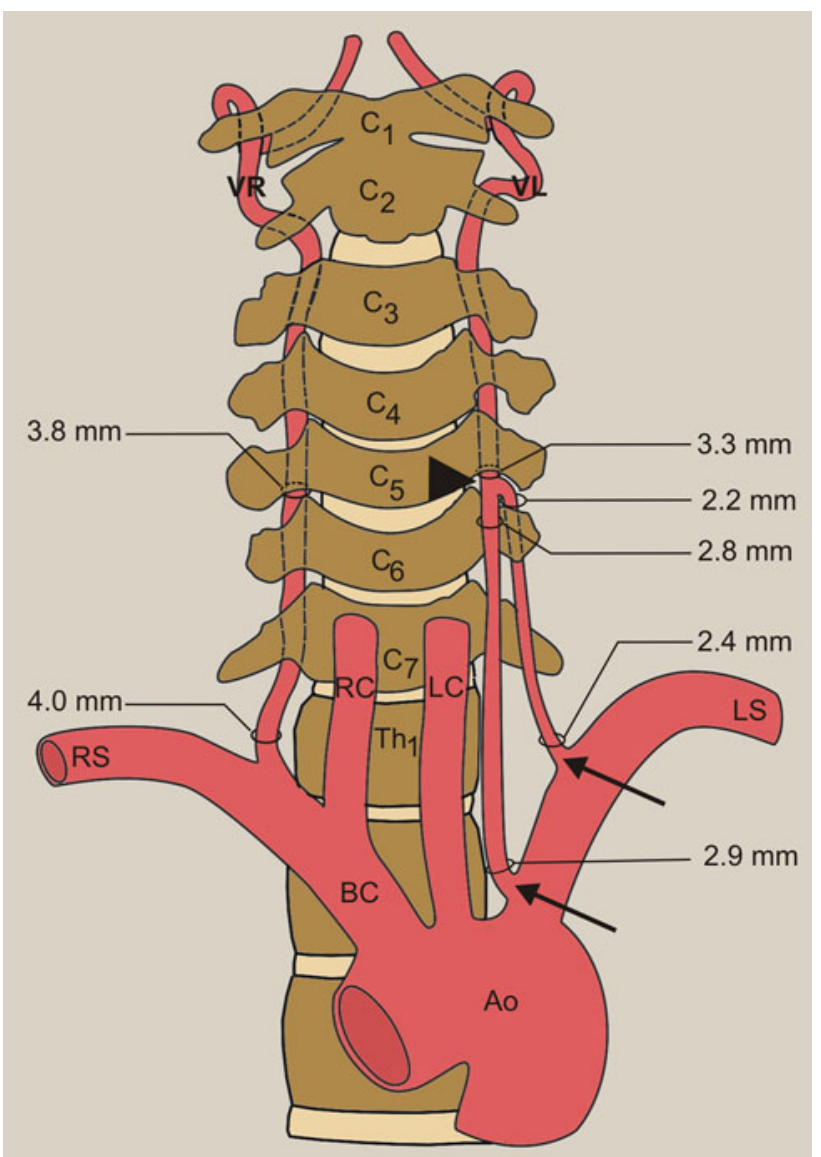

Fig. 4 Schematic arrangements of the vessels of the neck and measurements of diameter of the vertebral arteries: arrows origins of the duplicated left vertebral arteries, arrowhead level of fusion of duplicated left vertebral arteries, $A o$ aortic arch, $B C$ brachiocephalic trunk, $L C$ left common carotid artery, $L S$ left subclavian artery, $R C$ right common carotid artery, $R S$ right subclavian artery, $V L$ left vertebral artery, $V R$ right vertebral artery

as in the example presented in the paper, both duplicated arteries originate from the left subclavian artery (Table 1). Kiss (1968) describes a bifid origin of the right vertebral artery, one arising from the right subclavian artery and the other from the brachiocephalic trunk. Bergman et al. (1988) note the presence of dual vertebral arteries in 5 of 693 studied cadavers $(0.72 \%)$, and all were left-sided. In three of the specimens, the vertebral arteries arose as direct branches of the aortic arch, and the other two as a branch of the thyrocervical trunk. In all cases, a second ipsilateral vertebral artery arose from the subclavian artery.

Generally, the duplication of vertebral arteries is reported to be more common on the left side (Bergman et al. 1988; Goddard et al. 2001; Kendi and Brace 2009; Vasović 2004). However, when both arteries arise from the same subclavian artery, this variation is recognized more commonly on the right side (Table 1). Only Mahmutyazicioglu 


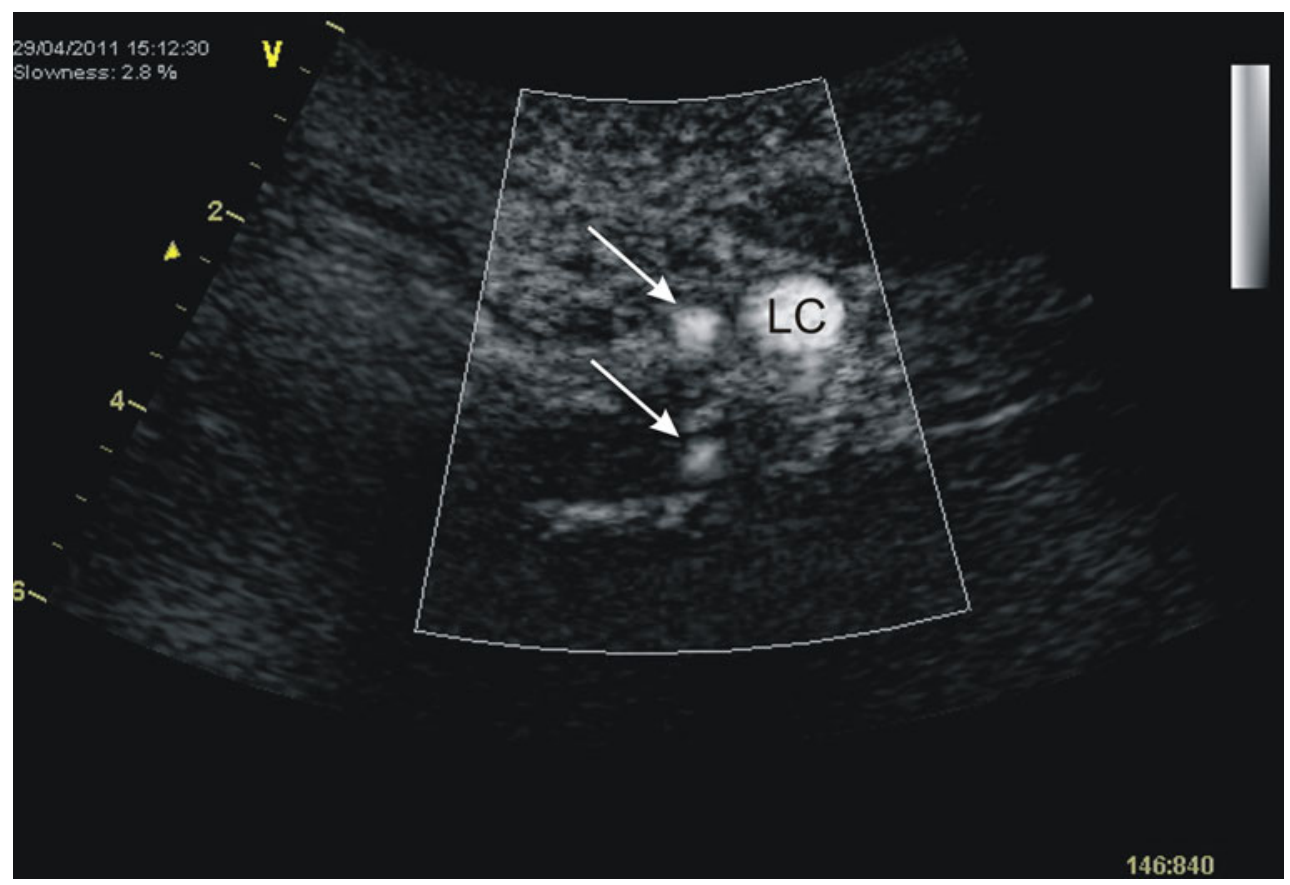

Fig. 5 Duplication of the left vertebral artery in Doppler ultrasonography (B-flow mode): arrows duplicated left vertebral arteries, $L C$ left common carotid artery

Table 1 Reports of duplicated vertebral artery when both originate from the subclavian artery

\begin{tabular}{|c|c|c|c|c|c|c|c|}
\hline Reference & Country & $\begin{array}{l}\text { Age } \\
\text { (years) }\end{array}$ & Sex & Side & $\begin{array}{l}\text { Level of } \\
\text { fusion }\end{array}$ & Disease and/or symptoms & Accompanying vascular anomalies \\
\hline $\begin{array}{l}\text { Babin and Haller } \\
\text { (1974) }\end{array}$ & France & 18 & $\mathrm{~F}$ & $\mathrm{R}$ & C5 & Epilepsy & $\begin{array}{l}\text { Dolichoarterial loop of the } \mathrm{L} \text { vertebral } \\
\text { artery }\end{array}$ \\
\hline $\begin{array}{l}\text { Hashimoto et al. } \\
\text { (1987) }\end{array}$ & Japan & 67 & M & $\mathrm{R}$ & C5 & $\begin{array}{l}\text { Temporal and cerebellar } \\
\text { infarction }\end{array}$ & None \\
\hline $\begin{array}{l}\text { Harada et al. } \\
\text { (1987) }\end{array}$ & Japan & 70 & $\mathrm{~F}$ & $\mathrm{R}$ & $\mathrm{C} 4$ & Occipital heaviness, dizziness & Hypoplastic L vertebral artery \\
\hline $\begin{array}{l}\text { Takasato et al. } \\
\text { (1992) }\end{array}$ & Japan & 37 & M & $\mathrm{R}$ & $\mathrm{C} 4$ & Brain-stem infarction & $\begin{array}{l}\text { Rudimentary and accessory } \mathrm{L} \text { vertebral } \\
\text { arteries }\end{array}$ \\
\hline $\begin{array}{l}\text { Mahmutyazicioglu } \\
\text { et al. (1998) }\end{array}$ & Turkey & 62 & M & $\mathrm{L}$ & $\mathrm{C} 2$ & $\begin{array}{l}\text { Vertigo, weakness and nausea, } \\
\text { thrombosis at the origin of } \\
\text { duplicated artery }\end{array}$ & None \\
\hline $\begin{array}{l}\text { Goddard et al. } \\
\text { (2001) }\end{array}$ & $\begin{array}{l}\text { Great } \\
\text { Britain }\end{array}$ & 66 & $\mathrm{~F}$ & $\mathrm{R}$ & $\begin{array}{l}\text { Mid- } \\
\text { cervical } \\
\text { region }\end{array}$ & Right cerebral infarct & None \\
\hline $\begin{array}{l}\text { Thomas et al. } \\
\text { (2008) }\end{array}$ & $\begin{array}{l}\text { United } \\
\text { States }\end{array}$ & 49 & $\mathrm{~F}$ & $\mathrm{R}$ & $\begin{array}{l}\text { Not } \\
\text { described }\end{array}$ & Not described & Mid-basilar trunk aneurysm \\
\hline $\begin{array}{l}\text { Harnier et al. } \\
\text { (2008) }\end{array}$ & Germany & 61 & $\mathrm{~F}$ & $\mathrm{R}$ & $\begin{array}{l}\text { Not } \\
\text { described }\end{array}$ & Dizziness & $\begin{array}{l}\text { Duplication at the right common carotid } \\
\text { artery, Fenestration of the left } \\
\text { common carotid artery }\end{array}$ \\
\hline Melki et al. (2012) & France & 51 & M & $\mathrm{R}$ & $\begin{array}{l}\text { Not } \\
\text { described }\end{array}$ & $\begin{array}{l}\text { Cervical artery dissection, } \\
\text { infarction of cerebellar vermis }\end{array}$ & None \\
\hline
\end{tabular}

$M$ male, $F$ female, $R$ right, $L$ left

et al. (1998) and the present study describe a duplication of the LVA originating from the left subclavian artery.

Several vascular anomalies coexisting with these variations have been reported: fenestration and duplication of the common carotid artery (Harnier et al. 2008), hypoplastic vertebral artery (Harada et al. 1987), arachnoid cyst (Ionete and Omojola 2006) and aneurysm (Kendi and Brace 2009; Koenigsberg et al. 2003; Mahmutyazicioglu et al. 1998; Suzuki et al. 1978; Thomas et al. 2008). 
Spontaneous dissection of the carotid or vertebral artery accounts for only about $2 \%$ of all ischemic strokes, but $10-25 \%$ of those occur in patients $<45$ years of age (Schievink 2001). Origin duplication of the VA is a relatively rare, clinically silent condition. However, some authors have speculated that fenestration and duplication of arteries is caused by "structures that split the flow and therefore divide the lumen". Hence, it appears possible that a misplaced squamous epithelium may cause such a split in blood flow or interfere with the complete fusion of embryonic brain-stem arteries, leading to a persistent duplication (Oldendorf 1989).

Drapkin (2000) and Nogueira et al. (1997) state that duplication of vertebral artery is clinically significant because it can be mistaken for a VA dissection, and therefore has therapeutic implications for interventional procedures using the proximal VA (V1 segment of the VA). Also, Gaskill et al. (1996) consider that duplicated vertebral arteries may be more predisposed to dissection. Dare et al. (1997) also report extensive vertebrobasilar CAD on a duplicated vertebral artery.

Schievink (2001) note that well-characterized genetic hereditary affections, such as autosomal dominant connective tissue disorders (Ehlers-Danlos syndrome type IV, Marfan's syndrome, autosomal dominant polycystic kidney disease, and osteogenesis imperfecta type I), might predispose the patient to dissections of arteries. This view is also supported by a report by Arnold et al. (2006); however, clinical signs of these disorders are present only in $1-5 \%$ of carotid artery dissection (CAD) cases (Schievink 2001). Fibromuscular dysplasias are frequently identified in about $11 \%$ of patients with an SVAD (Arnold et al. 2006) and in $15 \%$ of patients with a spontaneous CAD (Schievink 2001). These segmental nonatherosclerotic noninflammatory arterial diseases of unknown etiology commonly involve the renal and carotid arteries (Schievink 2001)

In 2001, Brandt et al. stated that, as the mechanical stability and elasticity of the vessel wall is provided by connective tissue elements, structural deviations in the main components, collagen and elastic fibers, may lead to functional impairment, pre-disposing to dissection of the arterial wall at given points of minor resistance. This is supported by Brandt et al. (2005), in histopathological studies of skin biopsy samples in patients with CAD. Scientists have discovered underlying ultrastructural abnormalities similar to those seen in patients with known hereditary connective tissue diseases. They also showed that about $55 \%$ had an underlying aberrant ultrastructural connective tissue disorder, whereas only $3 \%$ had clinical manifestation of connective tissue disorder such as Marfan syndrome. At least $5 \%$ of patients with CAD have a member of the family affected with CAD (Schievink et al. 1996).
The embryogenesis of the vertebral artery takes place between 32 and 40 days of development. At the $4 \mathrm{~mm}$ embryo stage, there are seven cervical intersegmental arteries, arising bilaterally from left and right primitive aortic arches. At the 7-12 mm stage, vascular connections between them exist. In this way the vertebral arteries are formed as fusion of the longitudinal anastomoses of the cervical intersegmental arteries. In the normal situation almost all intersegmental arteries regress, except the seventh, which forms the proximal portion of the subclavian artery, including the point of origin of the vertebral artery. Duplication of the vertebral arteries results from lack of regression of the right or left fifth intersegmental artery (Lie 1972; Padget 1948; Sim et al. 2001).

Understanding the topography and variations of the great vessels of the aortic arch is important for both the endovascular interventionist and the diagnostic radiologist. Thanks to modern imaging techniques, this knowledge has become more important in the era of carotid artery stents, vertebral artery stents, and new therapeutic options for intercranial interventions. To the best of our knowledge, extracranial duplication of the vertebral artery in patients with a coexisting spontaneous dissection of the ICA with Ehlers-Danlos syndrome has not been reported previously.

The lumen of the parts of the duplicated vessel were found to be smaller than normal. In this event, interventional procedures should be performed from the normal side if possible.

Conflict of interest The authors declare that they have no conflict of interest.

Open Access This article is distributed under the terms of the Creative Commons Attribution License which permits any use, distribution, and reproduction in any medium, provided the original author(s) and the source are credited.

\section{References}

Arnold M, Bousser MG, Fahrni G, Fischer U, Georgiadis D, Gandjour J, Benninger D, Sturzenegger M, Mattle HP, Baumgartner RW (2006) Vertebral artery dissection: presenting findings and predictors of outcome. Stroke 37:2499-2503

Babin E, Haller M (1974) Correlation between bony radiological signs and dolichoarterial loops of the cervical vertebral artery. Neuroradiology 7:15-17

Bergman RA, Thompson SA, AWW AK, Saadeh FA (1988) Compendium of human anatomic variation: text, atlas, and world literature. Urban \& Schwarzenberg, Baltimore, pp 71-72, 358-359

Brandt T, Orberk E, Weber R, Werner I, Busse O, Müller BT, Wigger F, Grau A, Grond-Ginsbach C, Hausser I (2001) Pathogenesis of cervical artery dissections: association with connective tissue abnormalities. Neurology 57:24-30

Brandt T, Morcher M, Hausser I (2005) Association of cervical artery dissection with connective tissue abnormalities in skin and arteries. Front Neurol Neurosci 20:16-29 
Dare AO, Chaloupka JC, Putman CM, Mayer PL, Schneck MJ, Fayad PB (1997) Vertebrobasilar dissection in a duplicated cervical vertebral artery: a possible pathoetiologic association? A case report. Vasc Endovasc Surg 31:103-109

Drapkin AJ (2000) The double lumen: a pathognomonic angiographic sign of arterial dissection? Neuroradiology 42:203-205

Gaskill SJ, Heinz ER, Kandt R, Oakes WJ (1996) Bilateral congenital anomalies of the extracranial vertebral artery: management with balloon therapy. Pediatr Neurosurg 25:147-150

Goddard AJ, Annesley-Williams D, Guthrie JA, Weston M (2001) Duplication of the vertebral artery: report of two cases and review of the literature. Neuroradiology 43:477-480

Harada J, Nishijima M, Yamatani K, Endo S, Takaku A (1987) A case of the duplicate origin of right vertebral artery. Neurol Surg $15: 321-325$

Harnier S, Harzheim A, Limmroth V, Horz R, Kuhn J (2008) Duplication of the common carotid artery and the ipsilateral vertebral artery with a fenestration of the contralateral common carotid artery. Neurol India 56:491-493

Hashimoto H, Ohnishi H, Yuasa T, Kawaguchi S (1987) Duplicate origin of the vertebral artery: report of two cases. Neuroradiology 29:301-303

Ionete C, Omojola MF (2006) MR angiographic demonstration of bilateral duplication of the extracranial vertebral artery: unusual course and review of the literature. Am J Neuroradiol 27:1304-1306

Kendi AT, Brace JR (2009) Vertebral artery duplication and aneurysms: 64-slice multidetector CT findings. $\mathrm{Br} \mathrm{J}$ Radiol 82:e216-e218

Kiss J (1968) Bifid origin of the right vertebral artery: a case report. Radiology 91:931

Koenigsberg RA, Pereira L, Nair B, McCormick D, Schwartzman R (2003) Unusual vertebral artery origins: examples and related pathology. Catheter Cardiovasc Interv 59:244-250

Lie TA (1972) Congenital malformations of the carotid and vertebral arterial systems, including the persistent anastomoses. In: Vinken PJ, Bruyn GW (eds) Handbook of clinical neurology, vol 12. North-Holland, Amsterdam, pp 289-339
Mahmutyazicioglu K, Sarac K, Boluk A, Kutlu R (1998) Duplicate origin of left vertebral artery with thrombosis at the origin: color Doppler sonography and CT angiography findings. J Clin Ultrasound 26:323-325

Melki E, Nasser G, Vandendries C, Adams D, Ducreux D, Denier C (2012) Congenital vertebral duplication: a predisposing risk factor for dissection. J Neurol Sci 15(314):161-162

Nogueira TE, Chambers AA, Brueggemeyer MT, Miller TJ (1997) Dual origin of the vertebral artery mimicking dissection. Am J Neuroradiol 18:382-384

Oldendorf WH (1989) Trophic changes in the arteries at the base of the rat brain in response to bilateral common carotid ligation. J Neuropathol Exp Neurol 48:534-547

Padget DH (1948) The development of cranial arteries in thehumanembryo. Contrib Embryol 32:207-261

Schievink WI (2001) Spontaneous dissection of the carotid and vertebral arteries. N Engl J Med 344:898-906

Schievink WI, Mokri B, Piepgras DG, Kuiper JD (1996) Recurrent spontaneous arterial dissections: risk in familial versus nonfamilial disease. Stroke 27:622-624

Sim E, Vaccaro AR, Berzlanovich A et al (2001) Fenestration of the extracranial vertebral artery: review of the literature. Spine 26:139-142

Suzuki S, Kuwabara Y, Hatano R, Iwai T (1978) Duplicate origin of left vertebral artery. Neuroradiology 15:27-29

Takasato Y, Hayashi H, Kobayashi T, Hashimoto Y (1992) Duplicated origin of right vertebral artery with rudimentary and accessory left vertebral arteries. Neuroradiology 34:287-289

Thomas AJ, Germanwala AV, Vora N, Prevedello DM, Jovin T, Kassam A, Horowitz M (2008) Dual origin extracranial vertebral artery: case report and embryology. J Neuroimaging 18:173-176

Vasović LP (2004) Reevaluation of the morphological parameters according to 11 different duplications of the fetal vertebral artery at prevertebral (V1) and intracranial (V4) parts. Cells Tissues Organs 176:195-204 